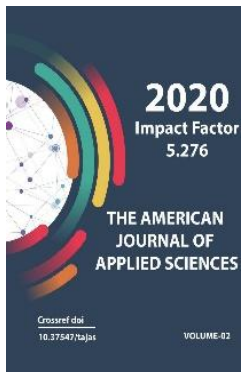

Journal Website: http://usajournalshub.c om/index,php/tajas

Copyright: Original content from this work may be used under the terms of the creative commons attributes 4.0 licence.

\section{Sources and Impacts of Oil Spills in the Niger Delta Region of Nigeria}

\author{
Etiese Etuk (PhD) \\ Clean Nigeria Associate Limited/Gte Arcon Shed, Nigerian Port Authority, Port Harcourt, \\ Rivers State, Nigeria \\ Emeka Ogbuene (PhD) \\ Centre For Environmental Management And Control, University Of Nigeria, Enugu Campus, \\ Nigeria \\ C.A Nwadinigwe (Prof.) \\ Department Of Pure And Industrial Chemistry, University Of Nigeria, Nsukka, Nigeria
}

\title{
ABSTRACT
}

Though crude oil production has its attendant high risks, it is one of the largest and most profitable businesses in the world. From its development phase to production phase, many disasters are bound to occur in the industries. Oil spill is the most important type of environmental disaster which usually occurs. It has impact on humans as wells as on plants and wild life, including birds, fish and mammals. Sources of spill ranges from equipment failures, human errors, accidents, sabotage and illegal bunkering activities on the production facilities. (Oil theft, sabotage and spills - Shell Companies in Nigeria publication April 2014). Good Industry operating and maintenance procedures are key to reducing incidents of oil spills. Prompt spill response management is a key success factor in reducing escalation of the attendant negative impacts on the environment by deploying a workable contingency plan suitable to the specific environment of importance.

\section{KEYWORDS}

Oil spills; Sources; Impacts; Niger Delta Region.

\section{INTRODUCTION}

Oil pollution has been of serious concern to the environment, especially the marine environment. The predominantly spill incidents in the Niger Delta Region of 
Nigeria spell doom to the marine ecosystem and by extension humanity. This becomes the key reason why we must collectively intensify efforts in sensitization, enlightenment and creating the required awareness on the prevention and reduction of this menace in our environment to assure future sustainability.

\section{STATEMENT OF PROBLEM}

Oil spills from several different sources are stigma to the environment and cause of concerns to all. The impact on the environment is massive with great degradation in the past decades. Areas of such impacts include contamination of water bodies, danger to aquatic life, destruction of flora and farmlands which includes resort centers, destruction of properties, loss of lives and many more.

\section{Objectives}

1. Review of appropriate literatures pertaining to the study

2. Investigation of the various sources and impacts of oil spills in the Niger delta region.

3. Investigation of the management systems used in controlling oil spills in the Niger delta region.

\section{SIGNIFICANCE OF THE STUDY}

The study has a significant role to play in discovering the different sources and impact of oil spills and approaches to prevent occurrence.

\section{SCOPE OF STUDY}

This study is focused on sources of oil spillage in the Niger delta region of Nigeria but particularly on the impact on the environment. This study is very important at the time to unravel the causes and sources of different spills that is responsible for the increasing environmental deterioration in the Niger delta region.

\section{SOURCES OF OIL SPILLS}

Oil spills on land could be caused by: 


\section{- Equipment failure}

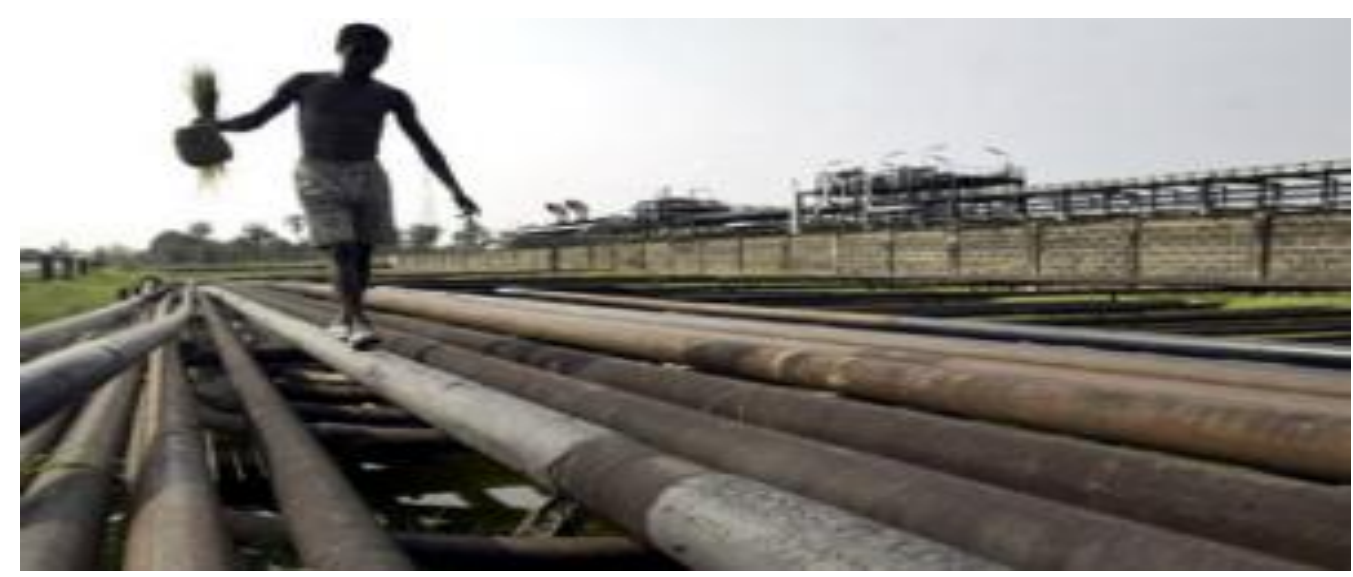

Table 1: Aged Pipeline. Source: Field visit

- Sabotage

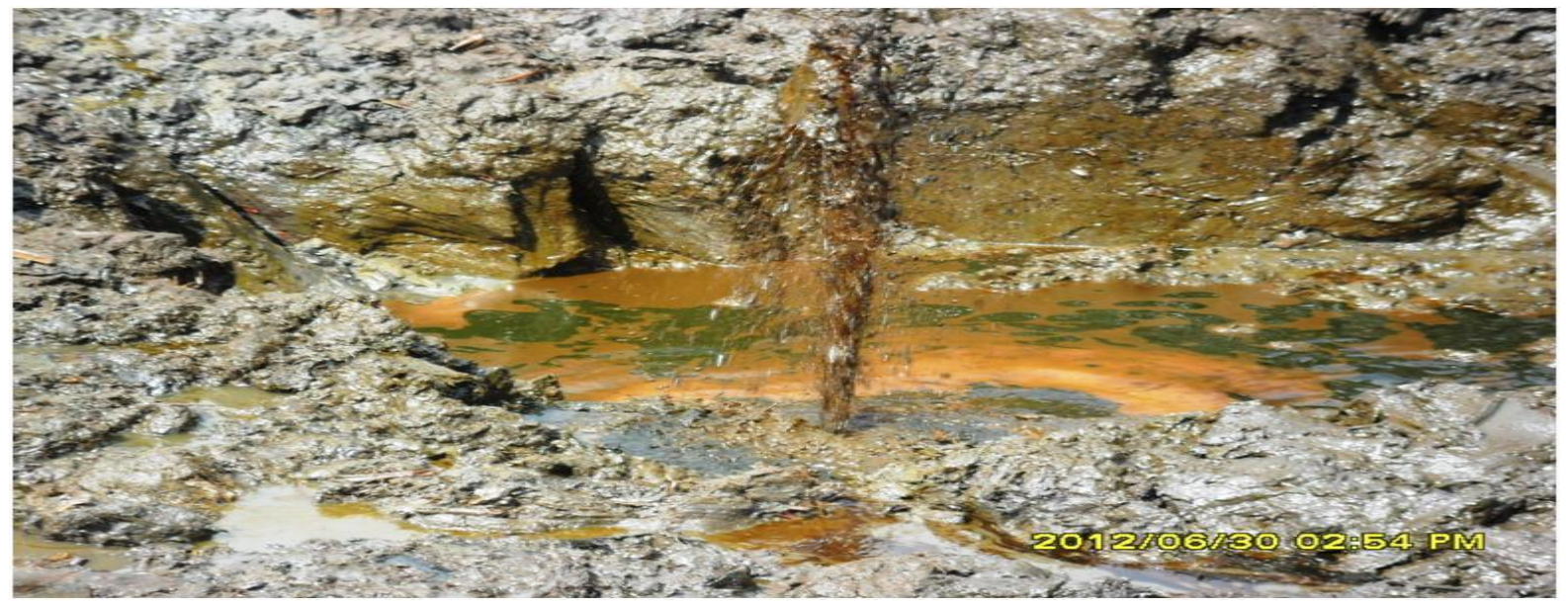

Figure 2: Leaking Pipeline.

- Bunkering and illegal refineries 


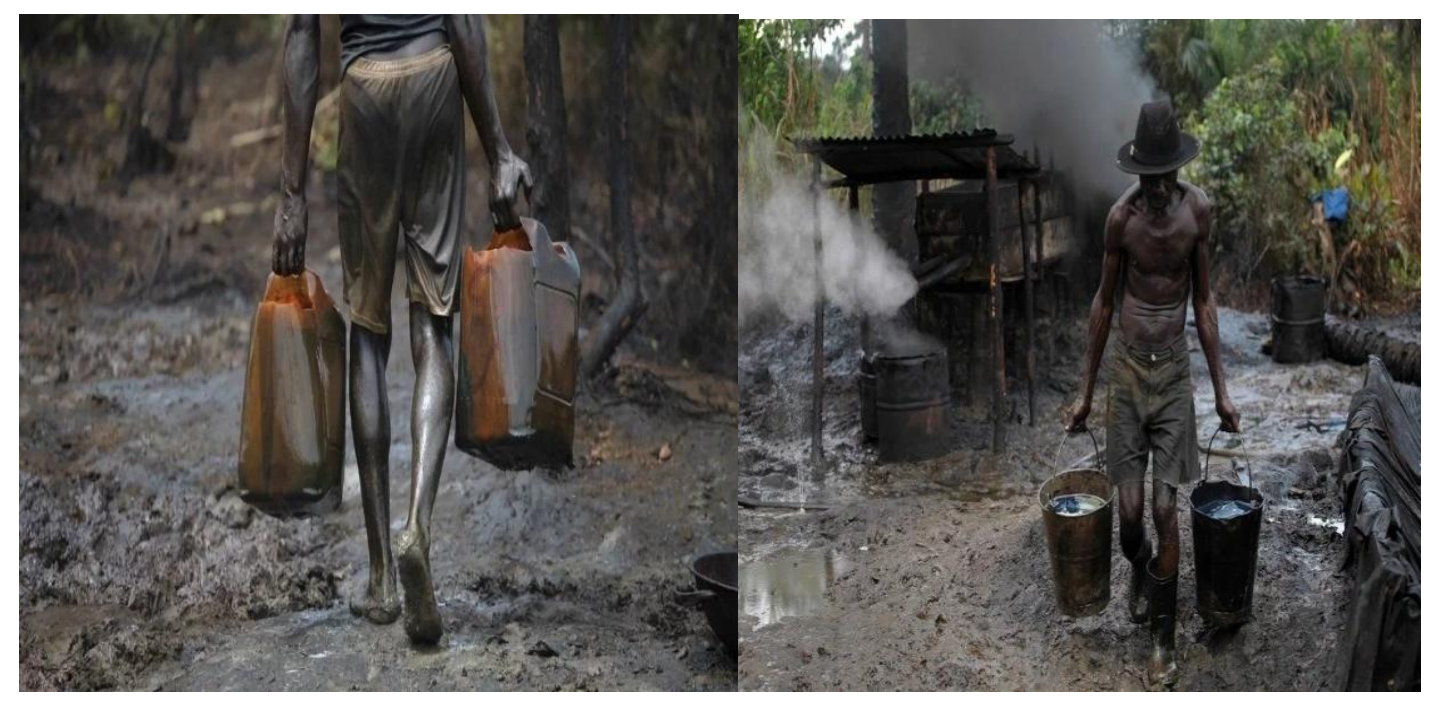

Figure 3\&4: Bunkering for Illegal Refining.

- Oil siphoning

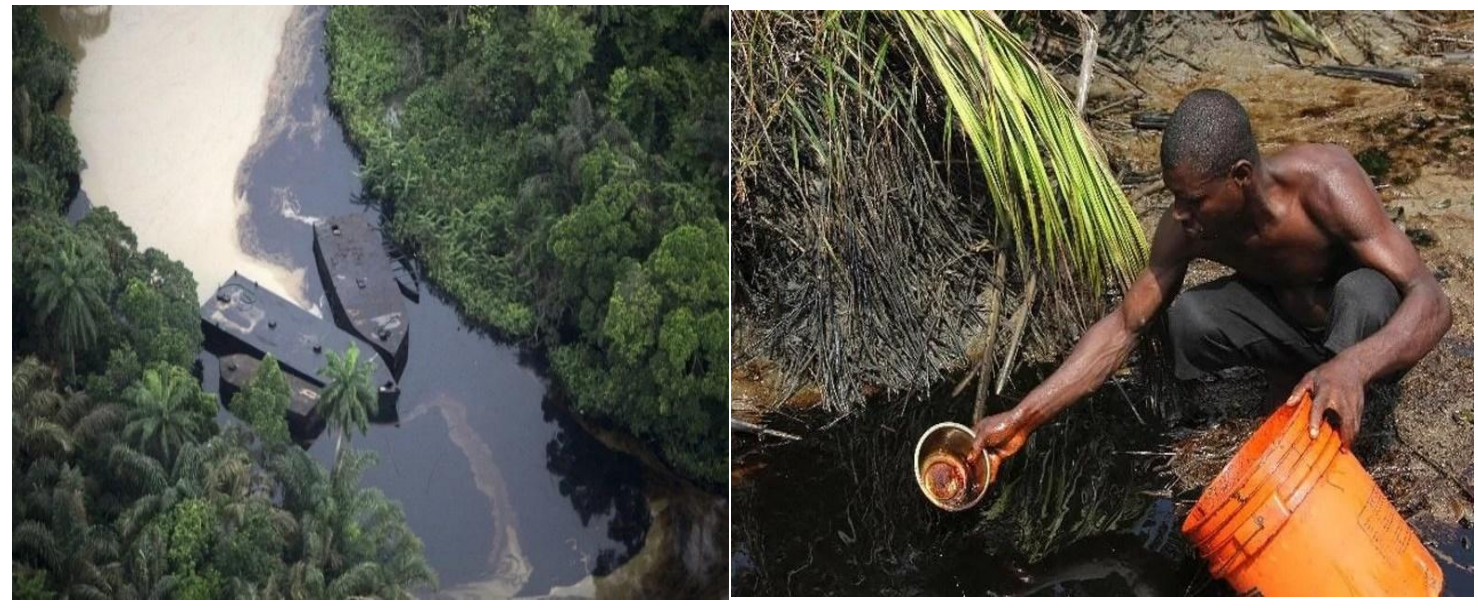

Figure 5\&6: Bunkering for Illegal Refining. 
The American Journal of Applied Sciences (ISSN - 2689-0992)

Published: August 13, 2020 | Pages: 31-44

IMPACT FACTOR

Doi: https://doi.org/10.37547/tajas/Volume02Issue08-05

- Terrorism,

- Production operations failure

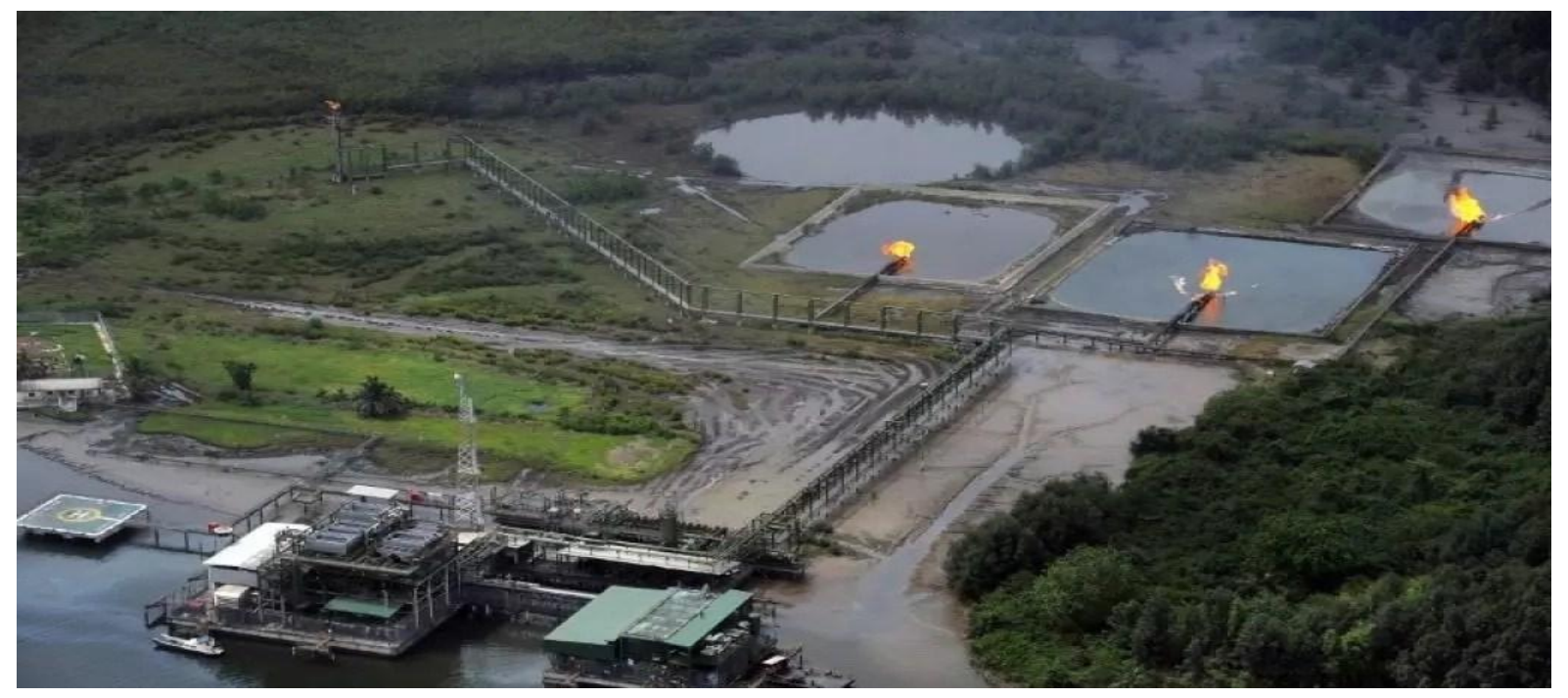

Figure 7:Operations Facilities.

- Human errors or equipment damage:

OIL SPILLS INTO RIVERS, BAYS, AND THE OCEAN MOST OFTEN ARE CAUSED BY

- Accidents involving tankers,

- Barges,

- Underwater Pipelines,

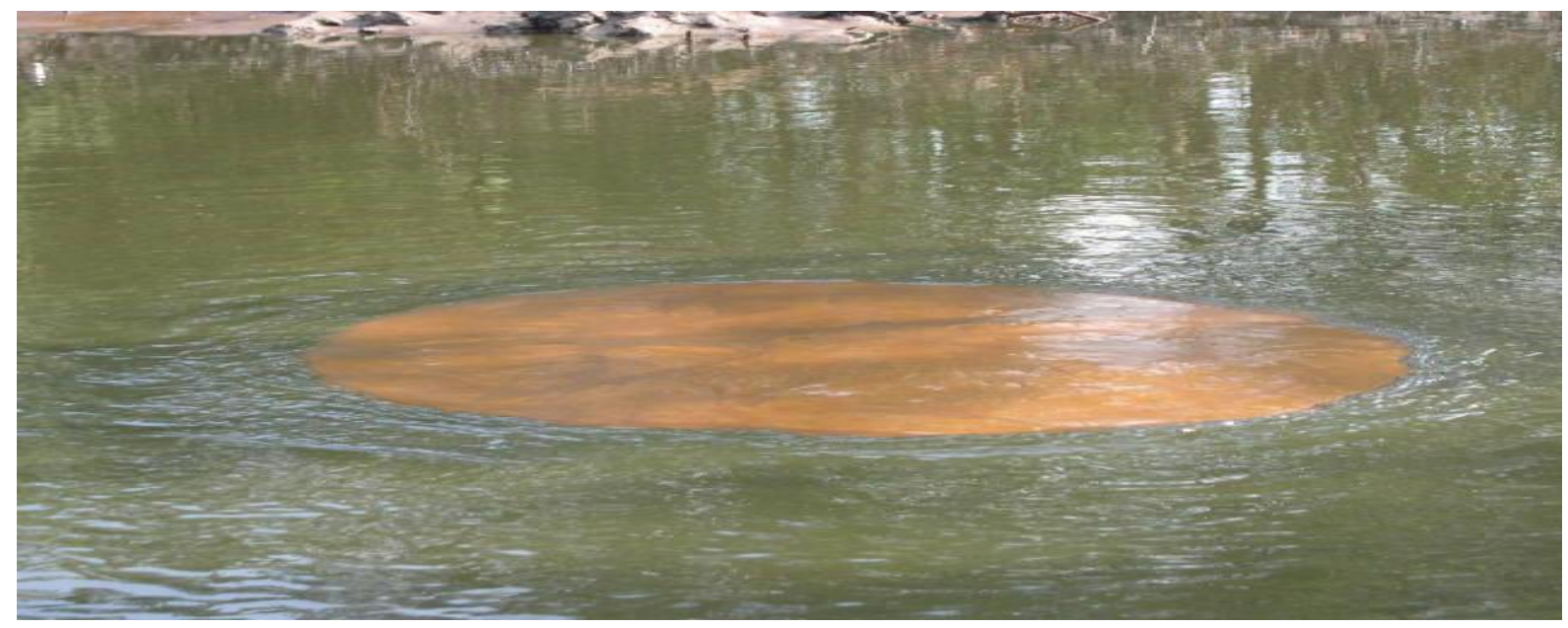

Figure 8: Leaking Underwater Pipeline.

- Refineries, 
- Drilling rigs and well blowout

- Damaged storage facilities as a result of human errors,

- Equipment failure and willful interference.

Tanker spill incidents are always very massive and will always require prompt intervention of

experts to avert and reduce the extent of impacts on the environment.

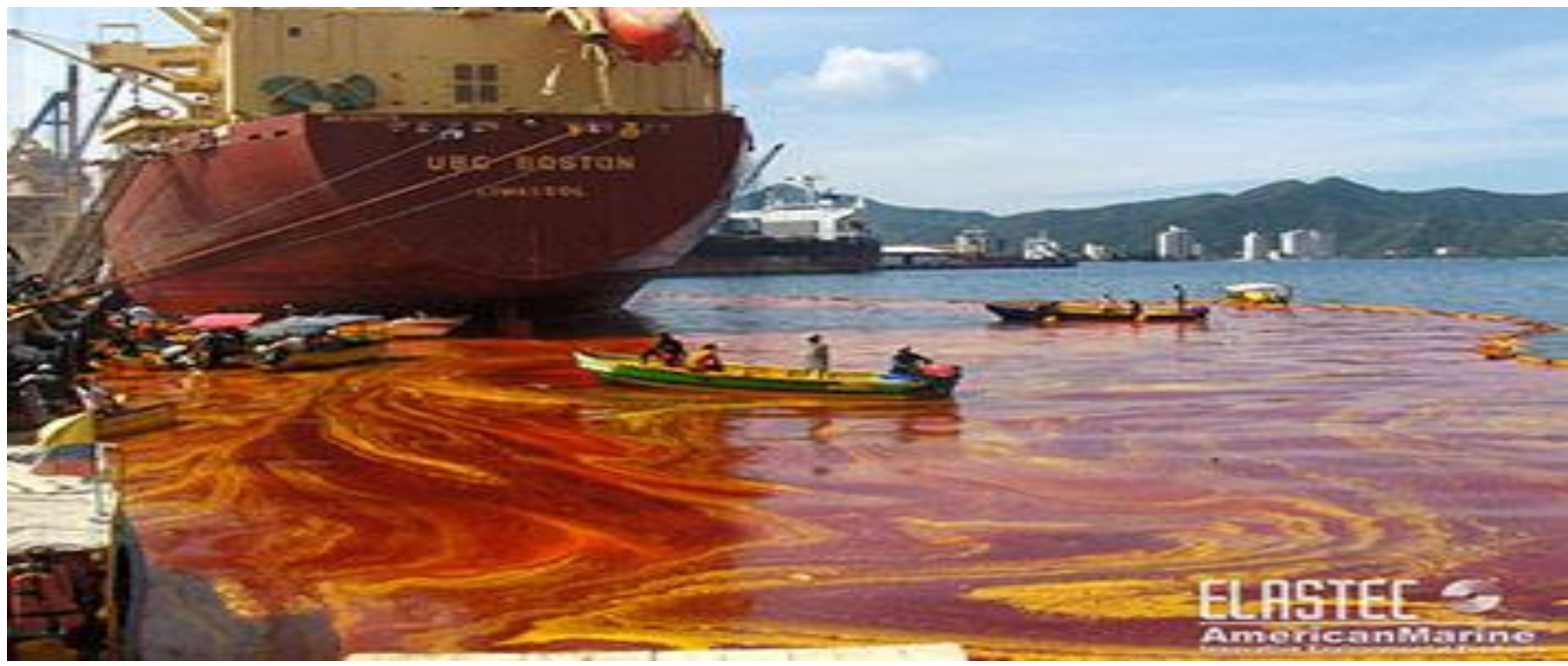

Figure 9: Aground Oil Tanker.

Oil spills could also be caused by natural disasters such as earthquakes and movement of tectonic plates.

- Impacts of Oil Spills:

- Human Health Risk:

The oil poisons the water and the food chain which in turns impacts on the health of the people by ingestion of toxic metals as well as the source of their livelihood. Again, oil spillage contains significant elements like $\mathrm{Cr}$ and $\mathrm{Ba}$ which are the common causes of skin ulcers, kidney and liver damage, breathing difficulties and eventual death 
The American Journal of Applied Sciences (ISSN - 2689-0992)

Published: August 13, 2020 | Pages: 31-44

Doi: https://doi.org/10.37547/tajas/Volume02Issue08-05

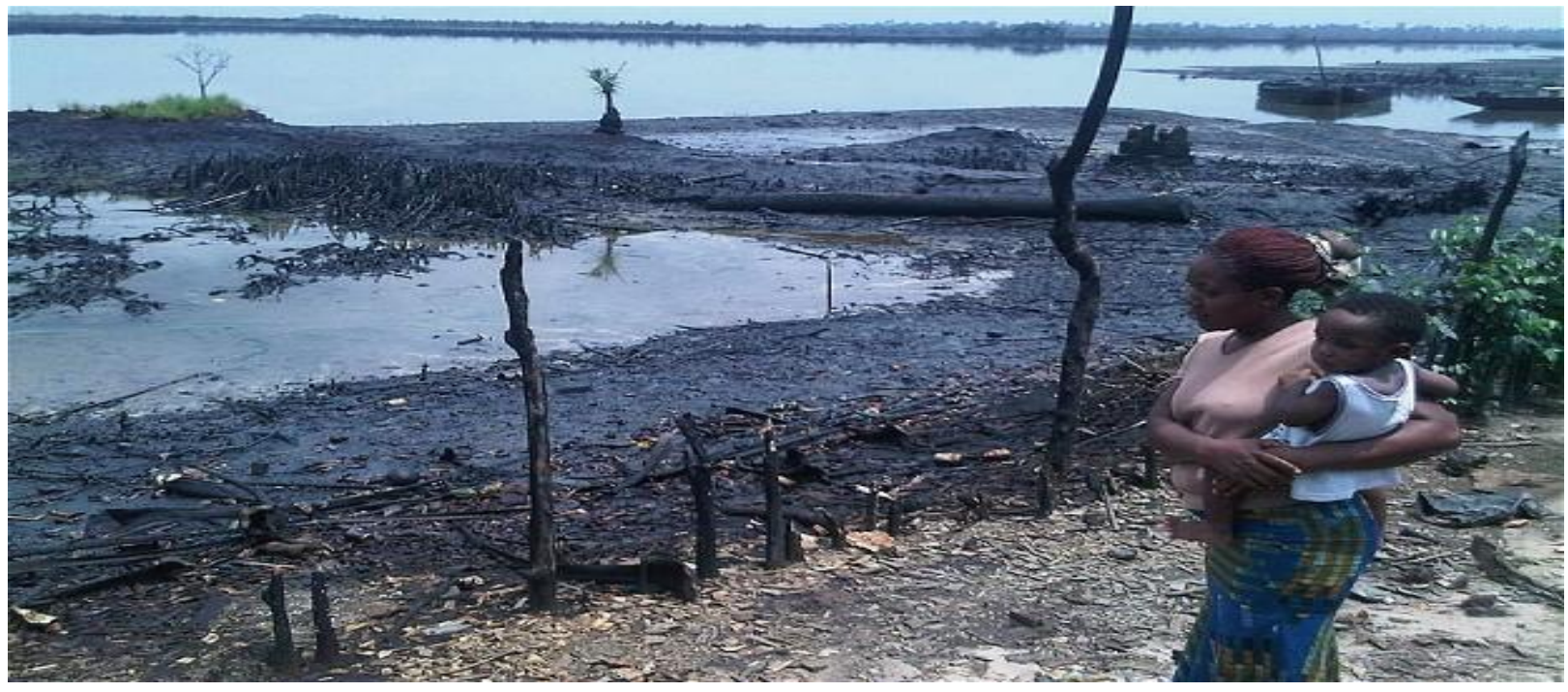

Figure 10: Polluted Ecosystem.

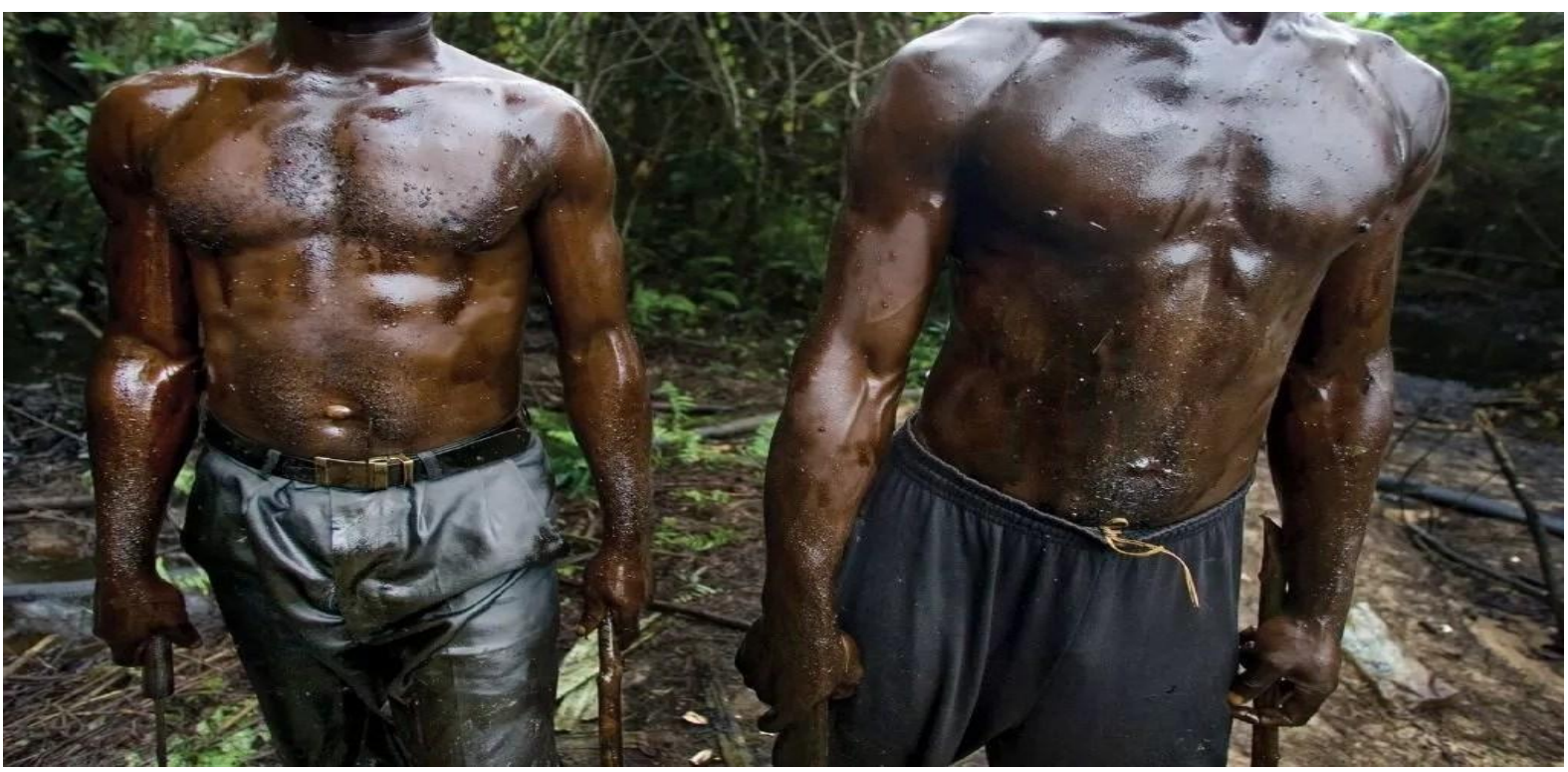

Figure 11: Potential Health Hazard.

\section{FOOD INSECURITY}

Most of the oil producing communities in the Niger Delta Region depend on fishing and farming for economic sustenance. Oil spills contribute to the fast depletion of fishes in the water than they are restored by reproduction in addition to over-fishing, climate change and habitat or nesting loss.

Oil contaminated soil losses the right fertility with the negative impact on yearly yield. [1]. 
There is no doubt that oil pollution caused by spillages from the oil industry located primarily in the Niger Delta region has done a great deal of harm to the region. Some past spills have necessitated the complete relocation of some communities, loss of ancestral homes, pollution of freshwater, loss of forest and agricultural land, destruction of fishing grounds, and reduction of fish population, which is the major source of income for the Niger Delta people [2].

\section{POLLUTED SEA FOOD}

Every sea food in contact with oil spill remains contaminated and not suitable for human consumption. The food chain is also threatened with sustainable negative impact on the health and wellbeing of potential consumers of the sea food.

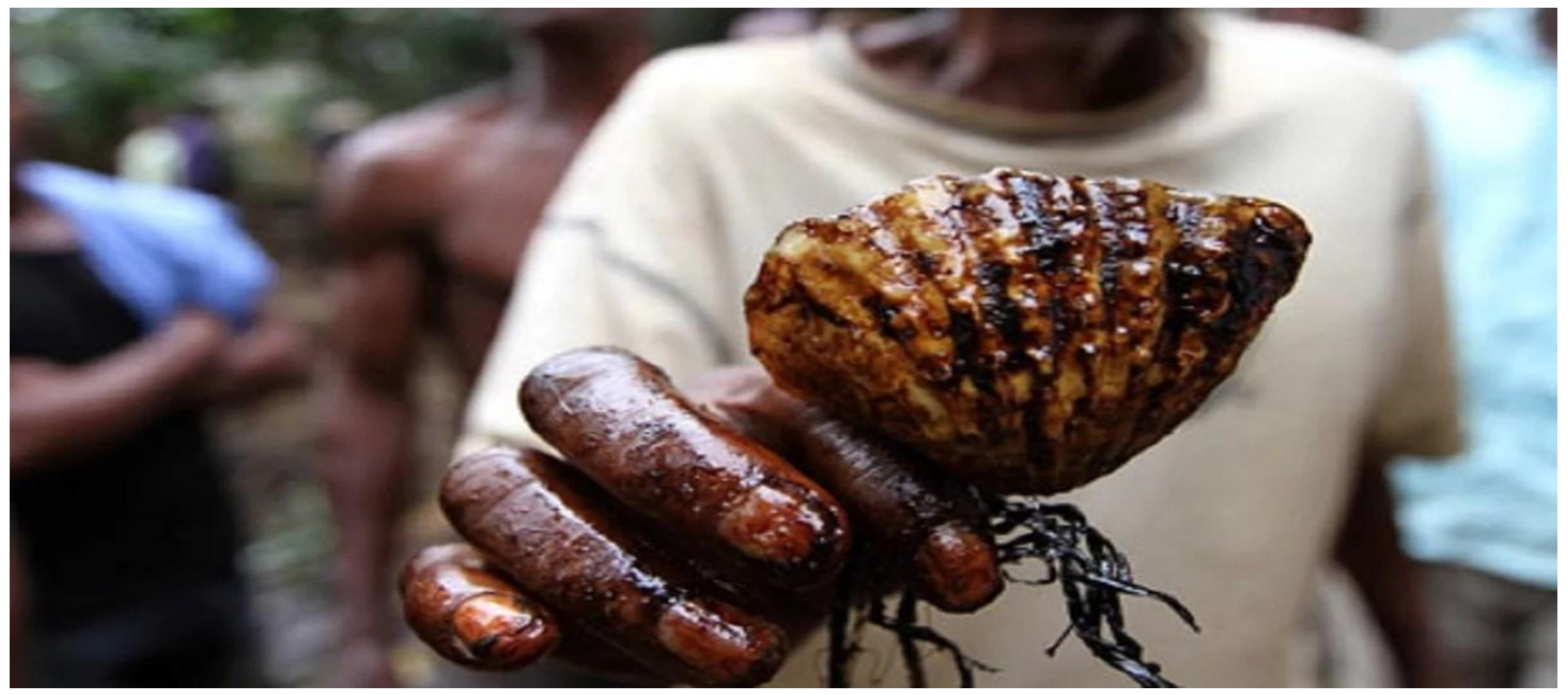

Figure 12: Contaminated Sea Food.

CONTAMINATION OF SURFACE WATER, GROUNDWATER AND SOIL

Spills impact on surface water like lakes and fishponds, soil and vegetations as well as the groundwater aquifer contaminating the natural water topography. 


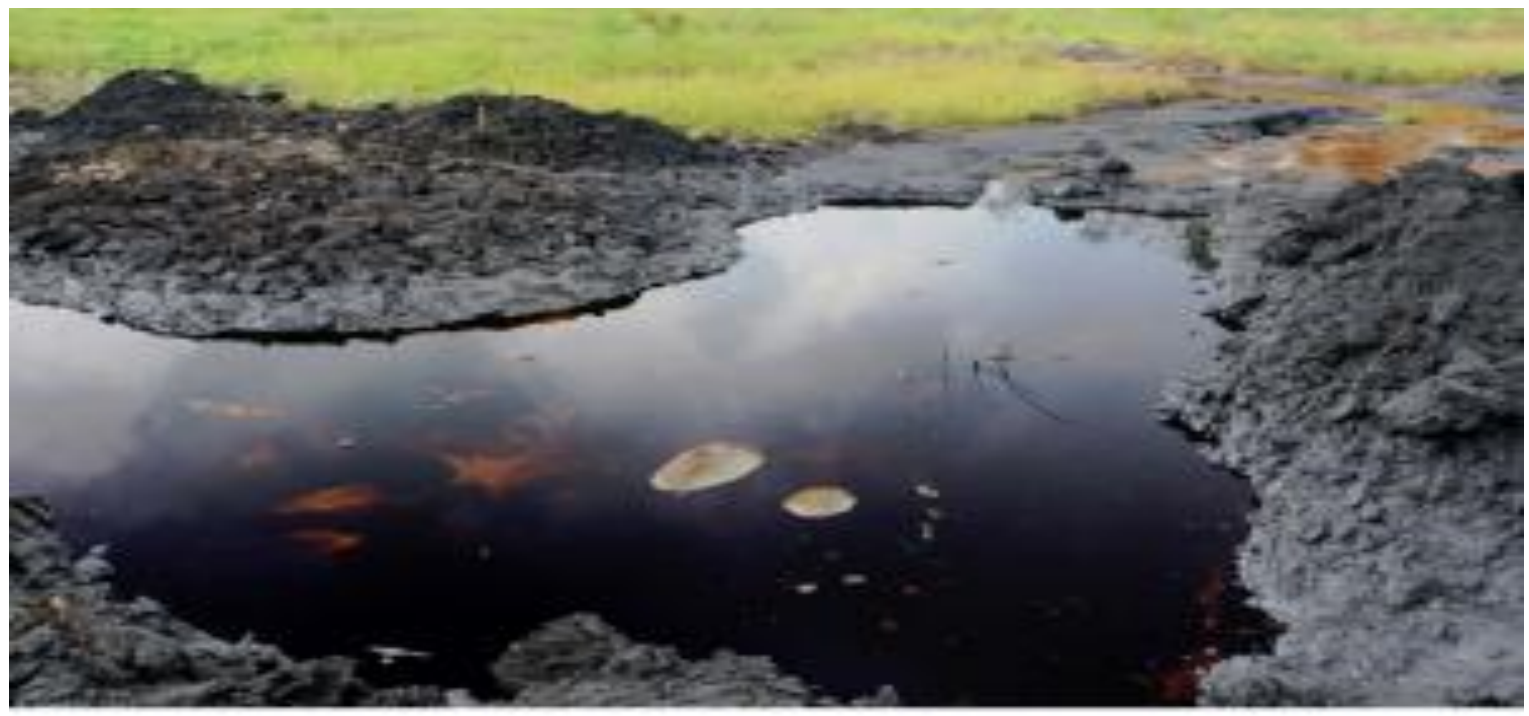

Figure 13: Polluted Ecosystem.

\section{ENVIRONMENTAL DEGRADATION}

The physical environment has so been devastated with consequences on the health, economies and the social lives of the people negatively impacted.

\section{DAMAGE TO THE ECOSYSTEM}

The impacts of oil pollution on the marine ecosystem are both long and short term with the attendant consequences on the economic power of the people.

The disruption in ecosystems by oil spillage has significant impacts on the ecosystem into which it is released. Vast areas of the mangrove forests in the region (which are especially susceptible to oil) have been destroyed. It is estimated that $5 \%$ of Nigerian mangrove ecosystems have been wiped out by crude oil spill. The rainforest, earth's oldest living ecosystems, which previously occupied more than $7,000 \mathrm{~km}^{2}$ of land has disappeared as well 


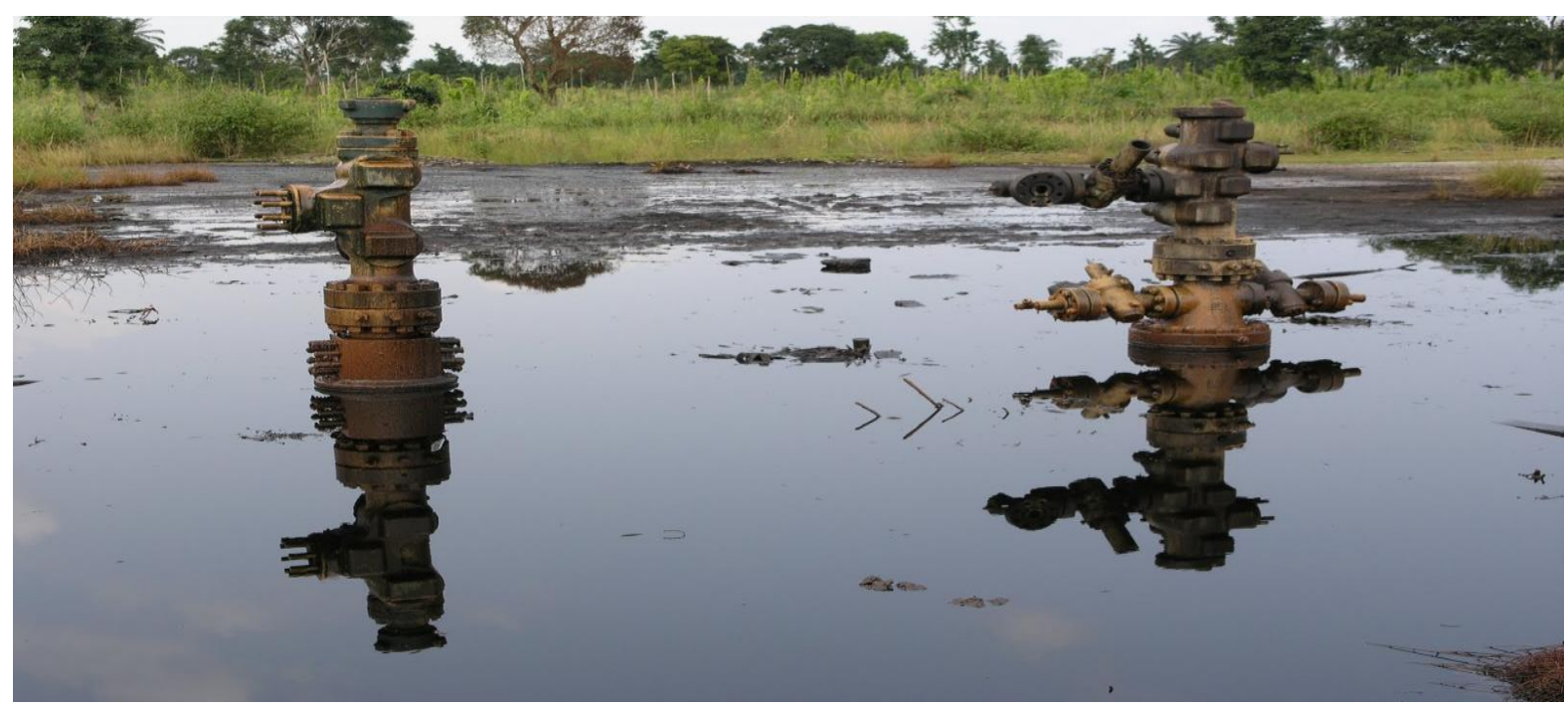

Figure 14: Polluted Soil and Vegetation.

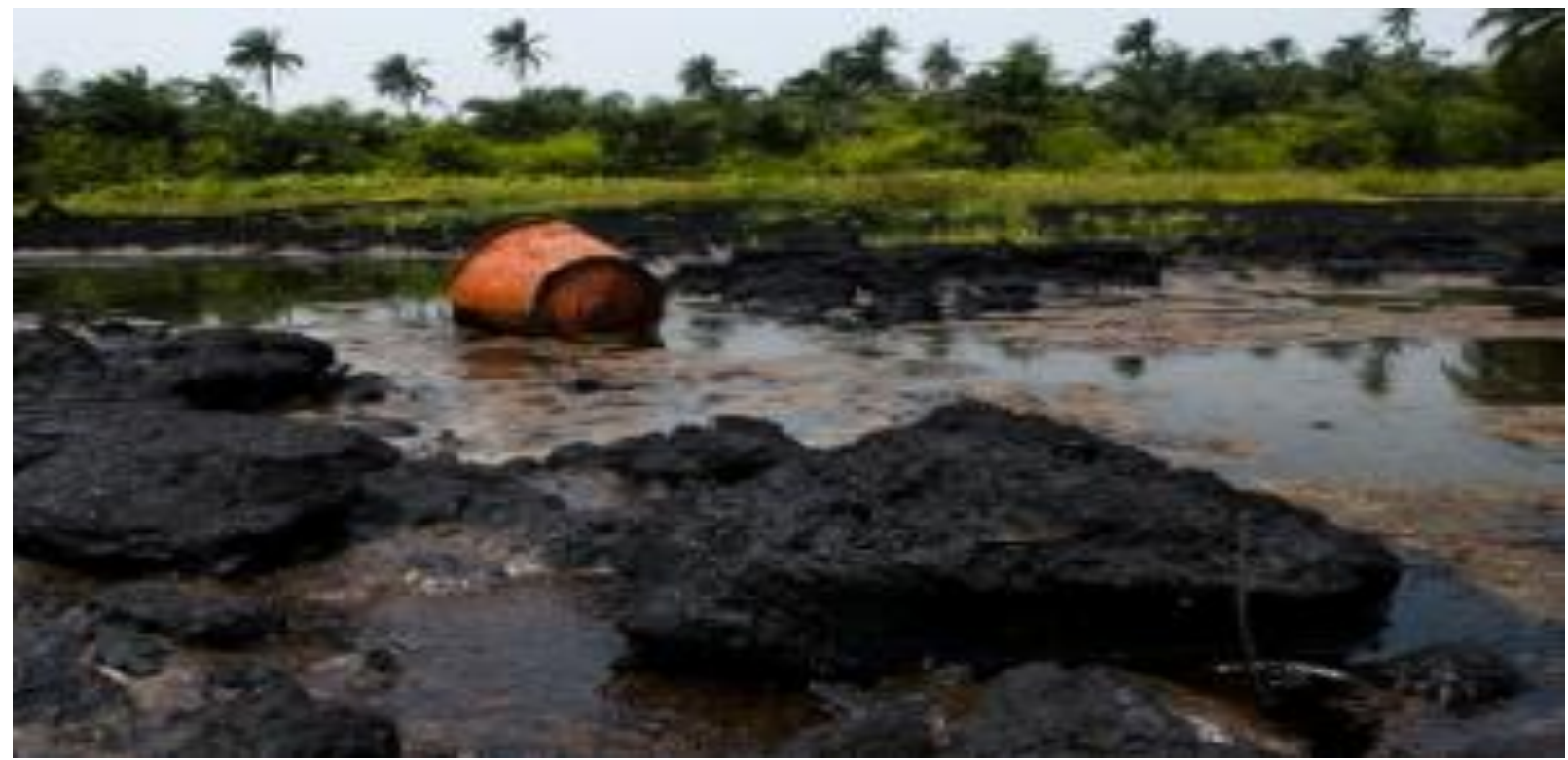

Figure 15: Polluted Rainforest. 


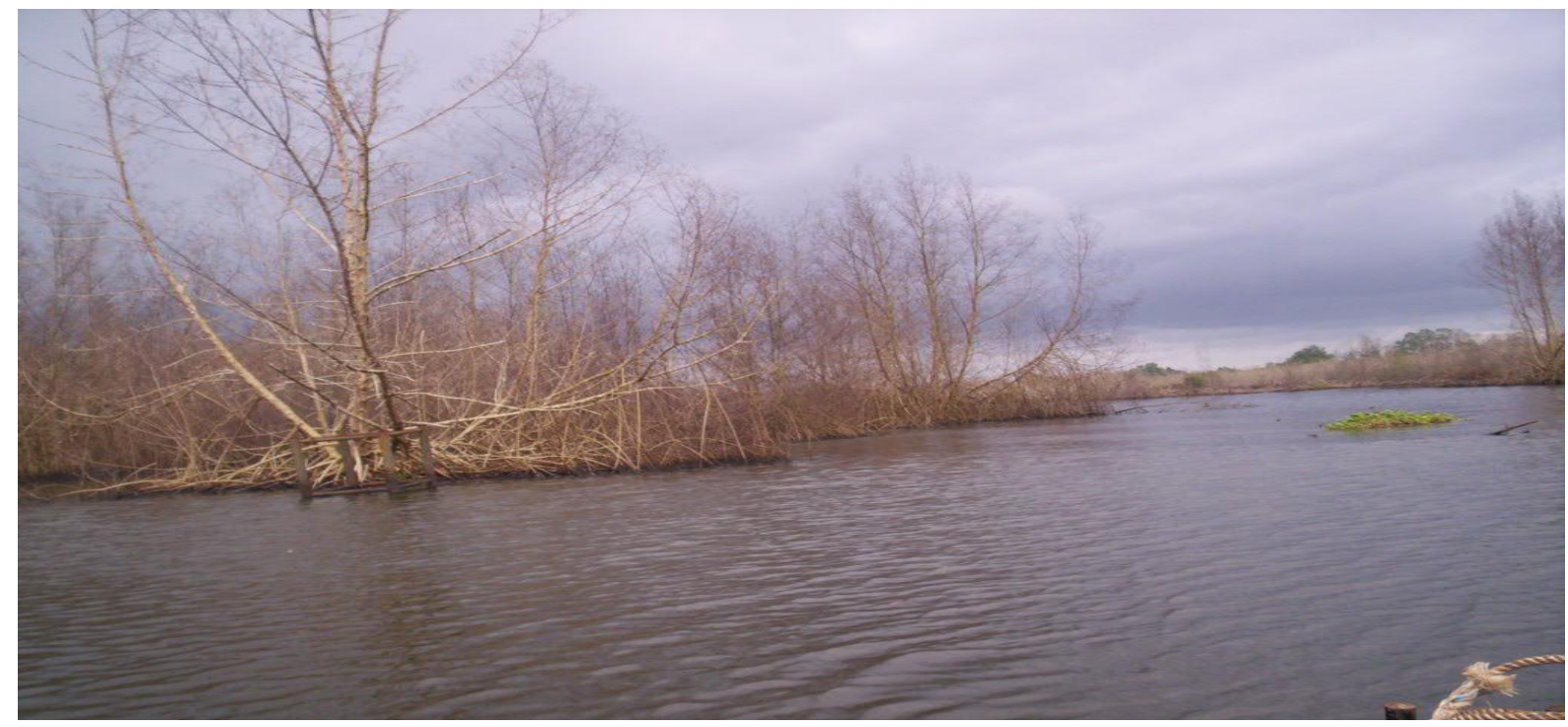

Figure 16: Impacted Mangrove Forest.

\section{LOSS OF AQUATIC PLANTS AND MAMMMALS}

Oil suffocates and kill a greater number of our marine mammal with attendant extinction threat. Crude oil has been shown to be embryotoxic, and its ingestion during egg formation and the laying period may affect the development of progeny [3].

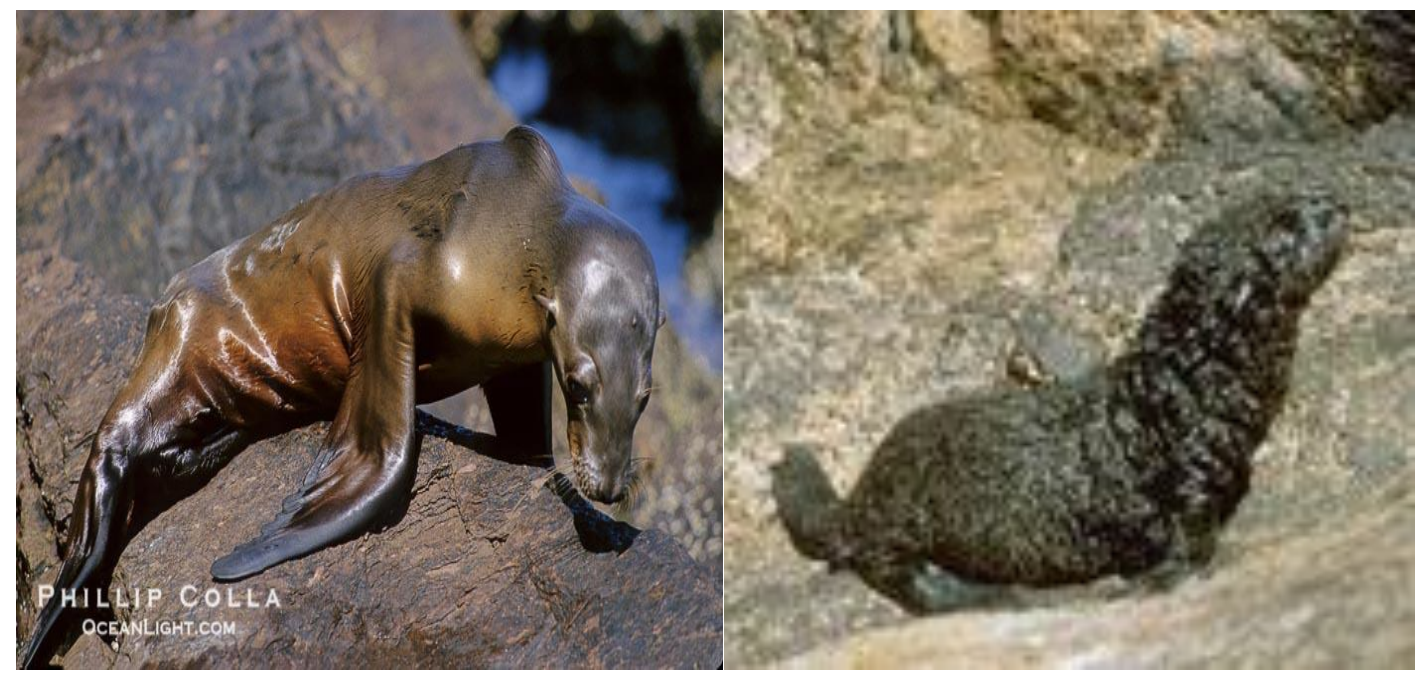

Figure 17\&18: Impacted Mammals. 


\section{DEPLETION OF FISH POPULATION:}

The oil contain polycyclic aromatic hydrocarbons (PAHs) which is the most toxic components of oil. Oil vapors can cause damage to the fish's central nervous system, liver, and lungs. Spilled oil can also have longterm reproductive problems in fish that have been exposed to oil.
[4] also reported that as little as $0.1 \mathrm{ppm}$ of crude oil can seriously affect fish, amphibians, crustaceans, plankton and sea worm. Crude oil has the potential to kill quickly by coating aquatic lives and interfering with gas exchange necessary for life.

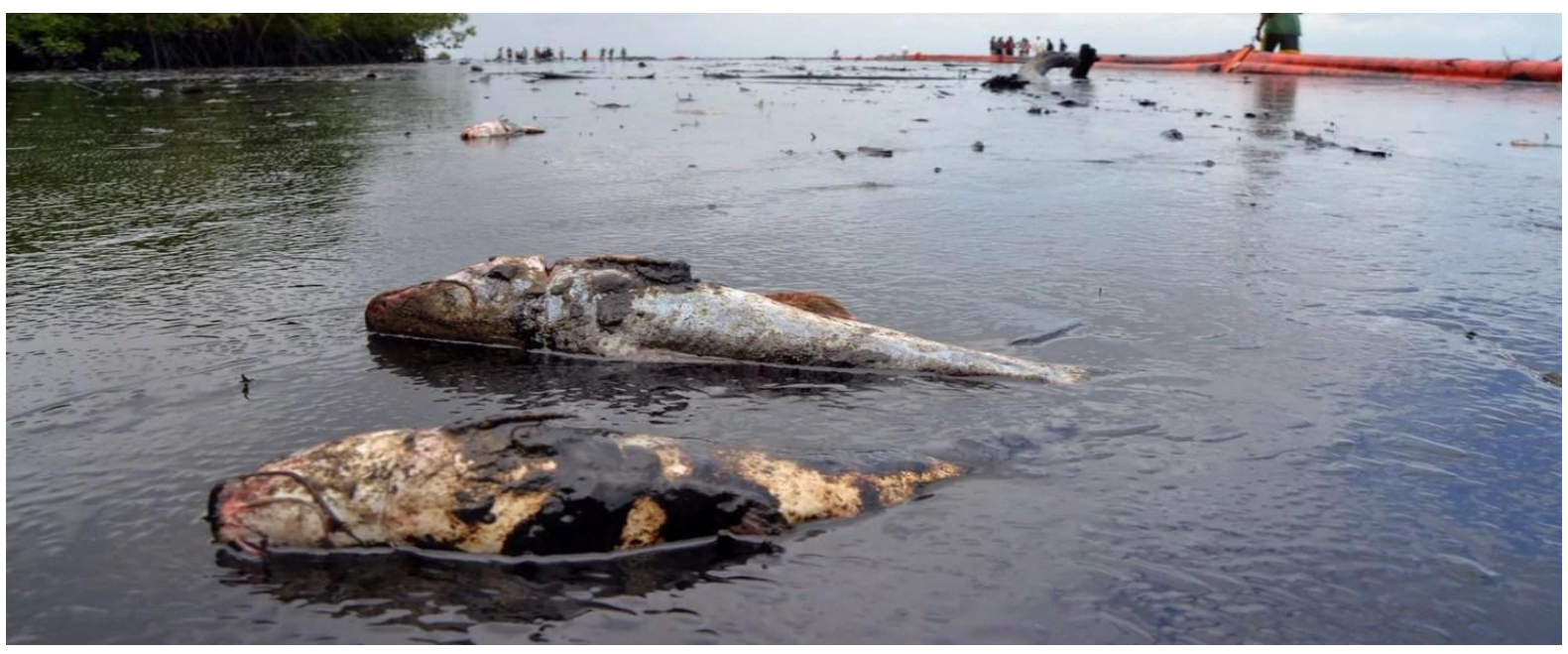

Figure 19: Impacted Fishes.

Source: Legit.ng Read more: https://www.legit.ng/1107470-oil-spillage-

nigeria-history.html

The contaminating impact has longer and perhaps more severe effects on benthic organisms [4]. [5], reported that physical environmental disturbances directly affect fish at the ecological level by rupturing fish assemblages and causing fragmentation and loss of genetic variability in fish populations.

Thus, crude oil exploration poses grave danger to the biodiversity of the aquatic ecosystem.

\section{LOSS OF BIRDS}

By coating the feathers with oil, it becomes impossible for birds to fly since their natural waterproofing and insulation abilities are hindered, leaving them vulnerable to hypothermia and eventual death. Oil toxicity also poses danger within 48 hours after a spill on different species of birds by reducing their fur insulating ability and damaging their water repellent nature. 

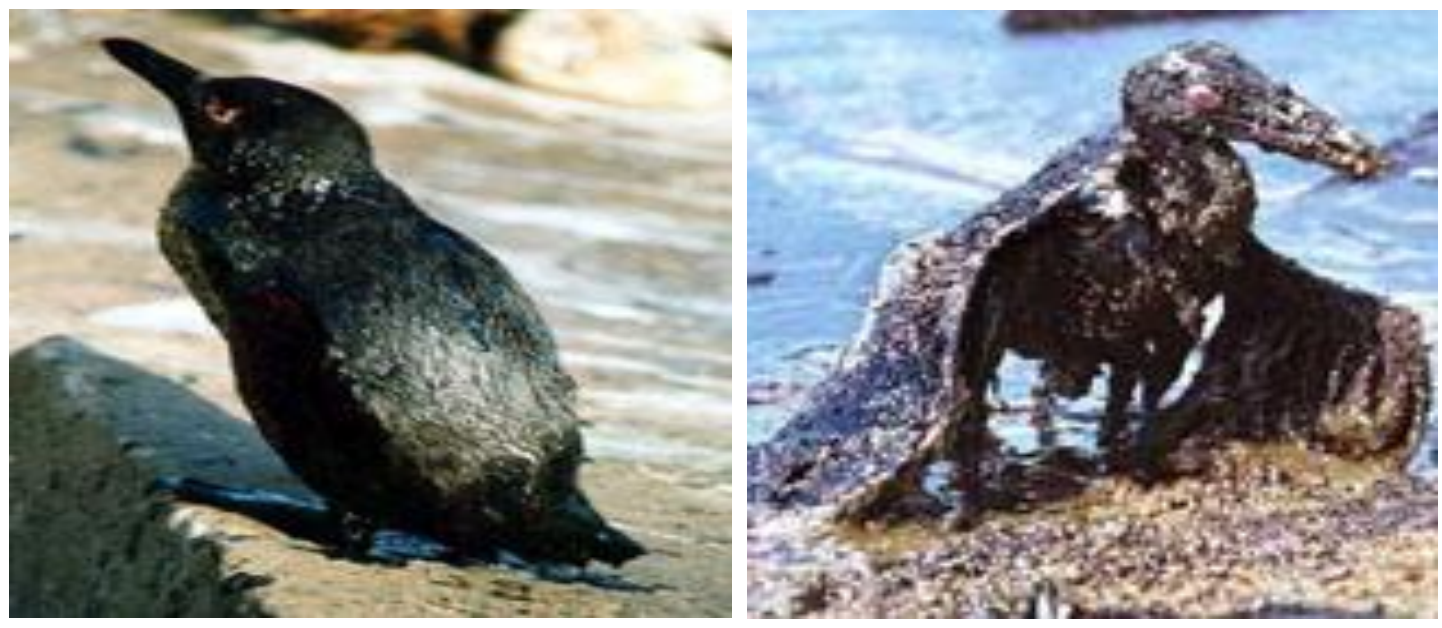

Figure 20\&21: Impacted Birds.

\section{ACID RAIN/OCEAN ACIDIFICATION}

Acid rain will produce corrosive water which will further pollute the water source with serious health implication. Acid rain affect plants and the soil negatively which leads to poor productivity.

The release of large amount of $\mathrm{CO}_{2}$ into the atmosphere by human activities, burnt spilled oil and gas flaring etc. have caused the amount of carbon dioxide in our atmosphere to rise dramatically. The water bodies absorb as much as one-third of all $\mathrm{CO}_{2}$ emissions in our atmosphere. This causes decrease in the $\mathrm{pH}$, resulting in the seawater becoming more acidic.

\section{CONCLUSION}

The main causes/sources of oil spill on the Niger Delta ecosystem are: vandalization of the oil pipelines by the local inhabitants; ageing of the pipelines; oil blow outs from production facilities, human errors, illegal refineries and many more.
The negative impacts from these sources of pollution are enormous and require prompt attention in response and clean up for environmental and economic sustainability.

Sensitization of the locals on the dangers and damages the spills are capable of causing to the environment will further reduce the frequency of occurrence.

\section{RECOMMENDATIONS}

- Implement every good industry practice to prevent and reduce oil spill impacts when it occurs.

- Adopt quick response strategy that will focus on protecting the most sensitive identified ecozones.

- Improve on knowledge base, education and training of spill responders.

- Tests contingency plans and industry response plans for responses to spills

- Provision of effective security surveillance of oil facilities. 


\section{REFERENCES}

1. Journal of Central European Agriculture 7(1) - October 2006).

2. Tolulope, A.O. (2004) Oil Exploration and Environmental Degradation. The Nigerian Experience. Environmental Informatics Archives, 2, 387-393 Gorsline \& Holmes, (1981) Long term Environmental Effects of Offshore Oil and Gas Development
3. Baker, et al. (1971). Reproductive biology, sexual dimorphism, and population structure of the deep sea hydrothermal vent scale-worm, Branchipolynoe seepensis . Journal of the Marine Biological Association of the United Kingdom 80 (1), 55-6

4. Sloman and Wood (2004) Behaviour and Physiology of Fish 63, 187-196. 